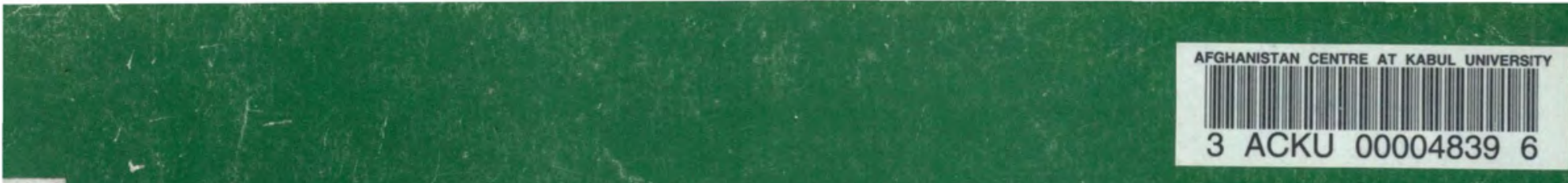

\title{
A PROMISE OF PEACE
}

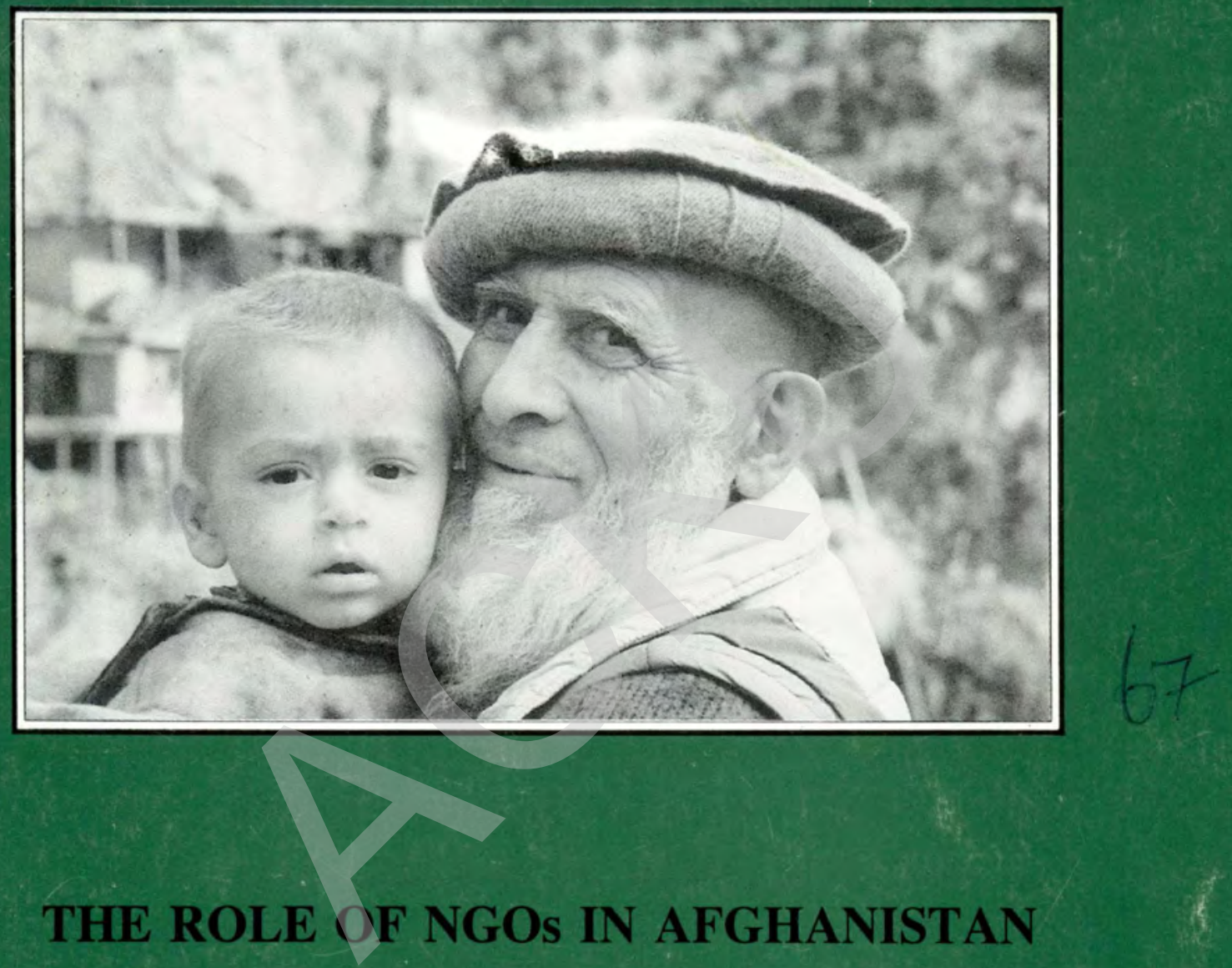

PRESENTED AT THE

BRIEFING OF DONORS ON AFGHANISTAN

STOCKHOLM

JUNE 1-2. 1995 
For further information contact:

Agency Coordinating Body for Afghan Relief (ACBAR)

2 Rehman Baba Road

University Town, Peshawar

Pakistan

TEL: (92-521)40839/44392

Compiled and edited by: Grace Huschle-Delobel

Cover photo: MADERA 


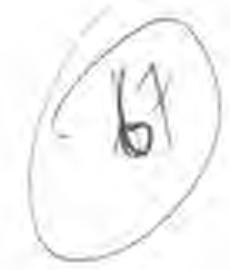

\section{ACKNOWLEDGEMENTS}

We would like to thank the following agencies for their contributions to this paper: ACBAR, Afghan Development Association (ADA), Afghanaid, Aide Medicale Internationale Afghanistan (AMIA), CARE, Dutch Committee for Afghanistan (DCA), Handicap International (HI), IIRO, Mission d'Aide au Developpement des Economies Rurales (MADERA), Mercy Corps International (MCI), Sandy Gall Afghanistan Appeal (SGAA), Save the Children/USA, Solidarites Afghanistan, SWABAC, and the Swedish Committee for Afghanistan (SCA). We also would like to thank the other NGOs and UN agencies who provided information used in the paper.

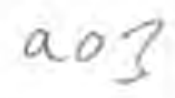




\section{FACT SHEET: AFGHANISTAN}

Afghanistan's rank in the Human Development Report 1993

Estimated population 1993

17 million

Number of people who became refugees during the war

6 million

Number of people killed during the war

1.5 million

Number of people maimed/disabled during the war

2.5 million

Mines remaining in Afghanistan

10 million

Life expectancy at birth

40-42 years

Infant mortality rate (per 1,000 )

Under 5 mortality rate (per 1,000)

304

Maternal mortality rate (per 10,000 )

100

Total fertility rate

Population with access to safe drinking water

Population with access to sanitation

Children suffering some degree of malnutrition

Literacy rate: female

male

Children of primary school age attending school:

girls

boys

Source: Afghanistan Rehabilitation Strategy: Action Plan for Immediate Rehabilitation, UNDP, October 1993. 


\section{CONTENTS}

PAGE

I. THE ISSUE $\quad 1$

II. THE PEOPLE

III. THE NGOS 2

A. THE NGOs' APPROACH

B. NGOs' SECTORAL ACTIVITIES

C. A PLEDGE OF PEACE: THE WORK OF NGOs 10

D. COORDINATION 11

IV. THE DONORS -11

$\begin{array}{ll}\text { V. RECOMMENDATIONS } & 12\end{array}$

$\begin{array}{lr}\text { VI. CONCLUSION } & 14\end{array}$ 


\section{A PROMISE OF PEACE}

\section{THE ISSUE}

Lets face it. Afghanistan is hardly worth considering for foreign assistance. The country has no functioning central government, lacks stability, and is the site of continuing warfare. It has little capacity to absorb development assistance and little potential as a major export market for international commerce. To top it off Afghanistan is a major producer of opium. Amid the many international claims on scarce assistance resources, it is difficult to justify putting significant funds into Afghanistan.

But viewed from a different angle, the picture is very different. Inside the borders of Afghanistan live approximately 17 million people, many of whom are slowly losing their long term struggle to survive.

And that is the crux of the matter. It is not whether Afghanistan should or should not be given assistance. The crux of the matter is that millions of people are losing their struggle to have adequate food, shelter, housing, clothing, education, basic health, and a sense of self worth. These needs should not be considered a luxury, but rather a right that should be extended to them.

Yet just as the need is increasing, funding is decreasing.

The reason for this conference on rehabilitation assistance to Afghanistan is that the lives of 17 million people are worth investing in.

\section{THE PEOPLE}

Afghanistan was an underdeveloped country before the war ever began, relying on a rural based economy with a large subsistence sector. Since 1978, the country has been invaded and occupied by foreign forces, then further torn apart by an ideological civil war and factional warfare. What was not destroyed by war has fallen into disrepair through the accompanying neglect.

Nevertheless, in the midst of this devastation there are and always have been peaceful areas adjoining ones of conflict. Over the years, the borders between these areas of peace and combat shifted with each attack and counter attack as the alliances of one day were undone the next. The civilian population thus became caught up in a hellish dance, at once hostage to the conflict and a struggle to survive. 
The current strife is the product of relatively few leaders, all of whom were originally or are currently supported by powers outside of Afghanistan. Today, young men are conscripted to fight in a war that they have no vested interest in, many killed in battles that will benefit neither them nor their country. Yet despite the ongoing fighting in certain areas, the situation in many parts of the country appears to be stabilizing, and the need for rehabilitation and development programs is thereby intensifying.

Major international and donor attention focuses on refugee return, the internally displaced, and on Kabul. But it must be remembered that most Afghans are not refugees, they are not internally displaced, and they are not in Kabul. Most Afghans are living in rural areas in conditions that are unacceptable by any international standard, and have done so throughout the long years of fighting.

The UN Development Committee has classified Afghanistan as the third poorest country in the world. A trip through some rural areas will find forests disappearing in a constant search for wood, fuel, and material for reconstruction. Large areas of agricultural land are unproductive, as mines lie in wait, and irrigation systems cannot be used because it is beyond the capability of villagers to clean and repair them. Animal productivity is low and mortality high due to a shortage of fodder and animal care. Few health facilities exist, and preventive health care teaching is virtually non-existent. Schools and roads have been destroyed, and there is no central government structure to get the country functioning again.

In spite of this, the people struggle on to eke out a living from a land and environment that is harsh and unforgiving. They do this, not out of choice, but due to the stark reality that they have no other options.

And although they receive far less international attention, there also are many regions in Afghanistan where life is returning to a relatively normal state. Canals are being cleaned and repaired, livestock herds rebuilt, mines removed, fields replanted, and schools reopened. While the need for new and continued assistance throughout Afghanistan is intense, these regions demonstrate the determination and potential of the Afghan people. They also indicate the positive impact the assistance thus far provided has had and suggest the opportunities waiting to be realized in the rest of the country.

\section{THE NGOs}

The nongovernmental organizations (NGOs) working in Afghanistan stand in the gap between available resources and peoplets need. During the years of conflict, the NGOs' programs followed the rhythm of the chaotic political situation, a rhythm set by conflict and the displacement of the population. NGOs tried to respond to needs where they arose and where it was humanly possible to provide a response. The NGOs' flexibility made them one of the preferred avenues of support for the Afghan people. Today, NGOs provide the backbone of the aid effort, particularly in rural areas. The aid channelled through NGOs in 1994 is noted below: 
Estimated Aid Provided Through NGOs in 1994

\begin{tabular}{lr}
\hline \hline Source & US\$ Million \\
\hline United Nations & 31.9 \\
European Union & 24.3 \\
Bilateral aid & 35.6 \\
Private & 6.0 \\
Other & 3.8 \\
\hline Total & 101,6 \\
\hline \hline
\end{tabular}

Roughly two types of NGOs operated during the period 1980-1990: the 'cross border' NGOs and the NGOs which worked exclusively in refugee camps. For ten years the 'cross border' NGOs were the sole means of assistance for the population remaining in Afghanistan. They gained considerable knowledge of the Afghan environment and wove durable ties with the largely rural population.

From 1989-1990 onward, the NGOs working in refugee camps began to focus their efforts on helping to resettle the uprooted population as they returned to Afghanistan. In this context, Afghan NGOs also emerged with knowledge of the milieu, technical skills, and a network of contacts.

The anarchic situation inside Afghanistan and the lack of an effective government have resulted in an aid process which has no equal. Circumstances have dictated a level and type of involvement on the part of NGOs that goes far beyond their traditional role.

\section{A. THE NGOS' APPROACH}

From the multiplication of seeds in Paktia to the rehabilitation of silk production in Herat, the restoration of irrigation systems in Logar to emergency aid for Kabul, NGOs working in Afghanistan are active in numerous fields, all of the provinces, and both emergency and development programs. The NGOs' programs are characterized by a focus on one or more of the following: a geographic area, a sector, and emergency, rehabilitation, or development activities.

Some NGOs have focused their assistance on one or more well defined provinces in which they support diverse activities. This geographic approach grants valuable knowledge of an area and enables the development of privileged relations with those who make and communicate decisions. Such programs rely on a sense of mutual confidence established over the years with the population. This facilitates a better definition of needs and encourages relatively strong 
community participation. The risks of pillaging and diverting aid also are limited or even eliminated as the communities assume the responsibility of policing themselves.

Other NGOs have focused their programs on a particular sector. The sectoral approach allows NGOs to make use of an acquired expertise based on a thorough knowledge of the realities of the field. This pragmatic technical knowledge enables NGOs to provide timely assistance when provincial or national strategies are implemented following discussions with government authorities and United Nations agencies. These 'technical' NGOs also are sources of expertise at the disposition of other organizations who wish to respond to a specific need that is beyond their own scope.

Lastly, some NGOs have focused on providing emergency aid, others on rehabilitation activities, and yet others on development programs. Even if the sequence emergency-rehabilitationdevelopment is open to discussion (emergency situations may coexist with a process of development in the same area; rehabilitation should not be considered only as the exact material reconstruction of what existed), the NGOs working in Afghanistan are now looking for ways of linking emergency assistance with development. The NGOs' knowledge of the field enables them to involve, from the emergency assistance stage, local structures and networks in the programs implemented. This consequently establishes a foundation for future reconstruction and development. The exchange of experiences and of skills between NGOs working on emergency programs with NGOs working on rehabilitation and development also helps to improve the overall quality of support provided.

\section{B. NGOs' SECTORAL ACTIVITIES}

NGOs are active in all of the major sectors in Afghanistan--agriculture, veterinary, forestry, irrigation, education, health, water and sanitation, housing, and demining. The NGOs' role in many of these sectors is described in the pages which follow.

\section{Agriculture}

Prior to the war, Afghanistan was self-sufficient in food production. However, years of conflict have directly or indirectly devastated agricultural production in the country. By 1988, crop yields on productive irrigated land had been reduced by $45-50 \%$.

The NGO community began to focus increasing attention on in-country food production in 1988. Between 1988 and 1994 more than 15,000 metric tons of good quality seed and an equal amount of nitrogen phosphate fertilizer were distributed to farmers in 25 provinces. A campaign was carried out to control locust and sun pest in the north and plant protection activities were undertaken in other parts of the country. NGOs also started rehabilitation work on the irrigation system, horticulture, and plant protection. An increasing number of organizations are shifting their staff and activities inside Afghanistan. 
In order for Afghanistan to achieve food self-sufficiency and eliminate or reduce the need of emergency food assistance, priority must be given to accelerated reconstruction and rehabilitation of agricultural production mechanisms. Self-sufficiency can be achieved through rehabilitation of irrigation systems, revival and strengthening of agricultural teaching and research institutions, establishment of crop variety testing and seed multiplication centres in all agro-ecological zones, facilitation of input availability in the local markets, and agricultural production credits.

In the absence of traditional governmental infrastructure for crop improvement, seed production and low input technology transfer, NGOs, the European Union, and UN agencies have assumed a coordination and leadership role to establish and strengthen the framework for these activities. Fortunately, the basic prerequisites for food production--land, water, and hard working Afghan farmers--are available in the country. They simply need assistance to realize their potential.

\section{Veterinary}

Emergency food supplies are still required in many rural areas of Afghanistan where farmers are barely able to produce enough food to feed their families. Traditionally, livestock always have been an economic buffer in times of insufficient crop production. During the war between $40-50 \%$ of the livestock population was killed or died due to a lack of veterinary services. Animal diseases are the major constraint to the recovery and restoration of the livestock sector. The shortage of draught animals due to this reduction in livestock is, in turn, a constraint to the rehabilitation of field crops.

Since 1987 several NGOs have begun to develop comprehensive and well coordinated community-based, private sector animal health care systems. A 1993 UNDP Project Evaluation Mission Report found that the policies and strategies designed by the NGOs were, "the best allround technical component of the UNDP/OPS project." The same report describes the methods pioneered by the NGOs in the veterinary sector as, "clearly better than anything that has been tried before, and should be used as a model for district level veterinary services throughout the country."

An impact survey was conducted in 1992 which found a decrease in animal mortality by approximately $22-30 \%$ in young animals and $30-60 \%$ in adult animals. The cost-benefit ratio of the veterinary programs was calculated at a maximum of 1:5. The veterinary programs designed and implemented by the NGOs therefore have proven to be highly cost-effective. By rebuilding the livestock population, they are making a critical contribution to the Afghan economy and the production of much needed food for the people,

\section{Forestry}

Seventeen years of war have created a vacuum over the control of the use of Afghanistan's forests, which are being threatened by indiscriminate commercial logging and the overgrazing of livestock. The most visible effects of the rapid deforestation taking place is land erosion and increasingly frequent and destructive floods. 
The conservation of the forest in Afghanistan is a long term concern that must be addressed today. The natural forests are a source of income that can be used to support the revival and further development of the rural economies. The forests are part of an integrated ecological system which forms the basis of these economies. They are a resource base that should be preserved for the benefit of both present and future generations of Afghans.

An example of the NGO approach to forestry is the Afghan Social Forestry Project (ASFP). begun in 1989 by several NGOs. Its activities include protecting regeneration in natural forests, replanting barren areas with fast growing tree species, making village forest inventories and maps, and an awareness program with the local communities about forest protection. These are implemented by foresters and village-based forest agents. The absence of a central government authority provides the opportunity to work directly with local communities who thereby assume greater responsibility for the management of the forests.

\section{Health}

The health situation in Afghanistan is currently one of the worst in the world. The existing health care infrastructure was almost completely destroyed during the war, as was the basic civil infrastructure, constituting a serious public health risk. The network of health facilities established largely by NGOs during the war is now in need of rationalization and standardization. The repatriation of refugees and economic rehabilitation efforts come at a time when urban basic services are poor, the conditions for epidemics are widespread, and people are malnourished. In brief, when the need for basic curative and preventative services is intense.

The health system currently is funded primarily by external assistance. During the years of war and conflict, NGOs were the main source of medical assistance for the people of Afghanistan, and they remain so today. NGOs have established countless health facilities, provided vast quantities of medical equipment and supplies, and trained thousands of Afghans as health workers. These people, many of whom now have valuable experience working in Afghanistan, are an extremely valuable resource who can amplify donor assistance many-fold. NGOs are now planning programs to rehabilitate and strengthen government health worker training institutions. NGOs also have established extensive immunization networks by training male and female vaccinators and establishing cold chains throughout the country. In collaboration with UNICEF, they have begun country wide vaccination campaigns for women and children.

Many of the major health problems in Afghanistan today are due to primary health issues such as poor water and hygiene, nutritional deficiencies, a lack of control of disease vectors, and insufficient management of epidemics. As such they need to be dealt with by a cross-sectoral approach. Medical NGOs therefore have been establishing bilateral and multilateral cooperations with NGOs in other sectors to broaden the front against primary health problems.

As the focus in health turns increasingly from emergency activities to development, the rationalization of the health system is imperative. NGOs are in the process of establishing technical and data-sharing coordinations. Sharing of resources and information, and the 
development of a database capable of accurately mapping natural social divisions, mean that these coordinations have a real chance of success in increasing economy and rationalization of resources. The re-entry of the UN to the health sector should be an opportunity to strengthen and support the systems and cooperations that exist, and must not ignore the essential resources that the NGOs command in terms of experience, human resource, and local political relationships.

\section{Disabled}

No one knows precisely how many disabled men, women, and children there are in Afghanistan. One source estimates that one in twelve Afghans suffer from some form of disability. Another source estimates one in six. What is clear is that nearly every Afghan family has at least one disabled member.

It is not just war and mine injuries which require attention. Polio is rife in many parts of the country, especially amongst the internally displaced population. Children suffer from cerebral palsy, club feet, hip displacement and hereditary and congenital disabilities.

Afghanistan never had a comprehensive orthopaedic service; what few facilities it possessed were largely destroyed by the war. Thus the only functioning government prosthetic service today is run by the Military Hospital in Kabul. There are no government prosthetic, orthotic, or paraplegic services outside the capital and access to physiotherapy is limited to a few major hospitals.

NGOs are striving to fill this gap. Four NGOs are operating prosthetic workshops in six different locations inside Afghanistan. Another three NGOs are located in Pakistan serving the refugees. Three NGOs are providing orthotic and physiotherapy services in Afghanistan; two in Pakistan. Components for orthopaedic workshops are manufactured by NGOs in Kabul, Quetta and Peshawar. Several of these programs will be expanded in 1995.

\section{Education}

Lack of basic knowledge by the bulk of the population is one of the biggest stumbling blocks to peace and development. People need tools in order to rebuild, to manage their lives, understand new ideas and plan for the future. Yet adult literacy and school enrolment rates in Afghanistan are among the lowest in the world. Only $14 \%$ of the women can read; only $44 \%$ of the men. Only $4 \%$ of the girls of primary school age are in school; only $27 \%$ of the boys.

The government is not able to do much, but it does support schools in some urban areas. Payments to teachers are irregular, as is the supplying of textbooks and other basic supplies. NGOs are making major contributions as they struggle to support local and central government efforts, rebuild such infrastructure as teacher training institutions and school buildings and, most critical, to bring basic education to rural as well as urban areas. This year 26 NGOs and three UN agencies collaborated on a workplan for 1995. The work is in progress and is impressive-- 
270,000 primary schools are receiving material support, supervision, and monitoring, 4,000 teachers and headmasters are under training, and a total of 17,600 adults $(5,800$ men and 11,800 women) are receiving education in literacy, arithmetic and basic health.

To date, NGOs have trained at least 20,000 teachers. Through the ACBAR Education Subcommittee, a data base has been established of all teachers trained since January 1992. The NGOs, UN, and the local and central government of Afghanistan are meeting together with promising results. A unified curriculum and set of textbooks have been agreed to by the major implementors and will hopefully be ready soon. Last year a framework with objectives and strategies was agreed to, again by the major implementors, and NGOs are working together toward an equal distribution of services, the sharing of resources and ideas.

\section{Women in Development}

The range and complexity of problems facing women living inside of Afghanistan today is daunting. The NGOs' response to the dismal health, social and economic position of the majority of Afghan women has been by necessity cautious. Attempts to address the underlying problem of women's low status have been limited as in many parts of the country this could lead to resentment and endanger the work and reputation of the NGO.

NGOs are implementing income generation, health and education programs for women. The income generation programs concentrate on culturally appropriate activities such as home-based poultry raising, quilt making, tailoring, embroidery and carpet weaving. Studies recently were made on starting micro-credit activities, and one NGO will be undertaking training in microenterprise management for women in Kabul. Many NGOs are involved in trying to improve the health status of Afghan women using both preventative and curative approaches. A lack of trained female health workers is, however, a major constraint. The education of women also is a sensitive issue. While primary education for girls generally is acceptable throughout the country, conservative communities are reluctant to let girls continue their education once they reach their early teens. NGOs have tried to address this by developing culturally appropriate and relevant adult literacy materials. Due to the negative experience of communist-style literacy classes during the Soviet occupation, some NGOs have combined female literacy classes with Quranic classes.

Capacity building of Afghan women's NGOs has been a difficult task due to the lack of partners with which to work. However, over the past 18 months a few international NGOs have been strengthening a major Afghan women's organization in Kabul. From being on the brink of closure two years ago, this organization is now providing valuable educational, health, and income generating services to women in the destroyed capital.

\section{Demining}

Over ten million mines remain scattered across a 466 square kilometre area in Afghanistan. The mines pose one of the most important threats to security in the country. They prevent vast areas 
of potentially good agricultural land from being utilized, and are a tremendous drain on communities' limited resources due to the long term care that must be provided to their victims.

The UN-sponsored demining operation in Afghanistan is being implemented by eight NGOs and employs over 3,000 Afghans. The program is organized into four components: mine awareness, mine clearance training, minefield survey and mine clearance. Of the total area mined, 118 square kilometres have been identified as priority areas for clearance. Since January 1990 nearly half of this area--54 square kilometres--has been cleared. If funding remains sufficient, the remainder could be cleared by the end of 1997 .

Despite the fact that the present de-mining operation is the most generously funded activity in the country, the task of demining is huge and requires both long-term planning and the capacity to effectively coordinate and support the actions of a wide variety of people and organizations who require their service.

\section{Urban Water and Sanitation}

Issues of urban water and sanitation in Afghanistan may best be described through the situation in Kabul. Before the war both the water and sanitation supply systems were plagued with problems. While Kabul has an excellent water table, only $60 \%$ of the city was supplied through water networks. The remainder relied on unregulated private wells which risked contamination. The city's sanitation system largely consisted of open sewers through which untreated waste flowed into the Kabul river. Solid waste was shovelled into trucks and brought to a dump outside of Kabul or used for fertilizer.

The war made a bad situation very much worse. Water networks shut down due to lack of electricity and the theft of equipment, and a proliferation of open wells were dug, increasing the wastage of water and pollution risks. The collection of waste ceased completely, thereby increasing public health risks considerably,

Since early 1994 NGOs working in Kabul have reacted quickly and effectively to both problems. Sixteen water supply networks were rehabilitated and now provide clean water to approximately 250,000 peopla. Over 350 wells have been sunk which are equipped with handpumps, lessening the risk of contamination. Programs were put in place using trucks supplied by the municipality to clean both solid and human waste from densely populated public and private places. These programs have been repeatedly credited by local officials for having reduced the outbreak of disease last summer.

NGOs were virtually the only organizations providing humanitarian assistance to Kabul during this time. Despite the dangers of war, difficulties of access to the city, and the poor state of its infrastructure, the most dire needs of Kabulis were met intelligently and efficiently. It is quite plausible that this success was a result of qualities intrinsic to NGOs: an ability to act quickly and directly to address specific problems, the need to achieve concrete results in order to maintain funding, and the capacity for imaginative solutions. The fact that NGOs were able to 
coordinate with each other is a final factor in their success in meeting water supply and sanitation needs in Kabul.

\section{A PLEDGE OF PEACE: THE WORK OF NGOS}

Beyond providing emergency relief and development assistance, the work of NGOs has and will continue to contribute to the peace process in Afghanistan. They are able to do so due to the very special character of their work which is intensive, carried out at the community level, and based on ties of confidence woven over many years with the Afghan people.

The NGOs which once worked in the camps are now accompanying the refugees as they return to their homes, their presence restoring confidence to people who have been tossed about by conflict. The daily presence in the field of NGO staff, sharing the same difficulties and risks as the population, give the latter another reason to resettle, rediscover their landmarks and live again in their villages.

The profound wounds of the seventeen-year conflict have left indelible scars on Afghan society. However, the intensive, painstaking efforts of NGOs to be in permanent contact with the real representatives of the community effectively diminishes the power of "commandants" and thus tends towards a rebalance of power. This is extremely sensitive work which must be carried out with prudence, but there are an increasing number of examples where the local population have demanded and obtained reparations when armed bands stole from projects implemented jointly by NGOs and the population.

All of the work done by NGOs, particularly in rural areas, aims to revitalize the economy at the family level by establishing the conditions for restarting agricultural activities (seeds, fertilizer, irrigation, animal health). These efforts are a catalyst to reviving the subsistence economy which was and continues to be critical to the survival of the majority of Afghans. At the same time, these activities support and strengthen the family unit, traditionally very powerful in Afghanistan, which is again becoming a place that each member, including the combatants, can or will be able to find a place.

Next to these traditional agricultural activities, NGOs are working to train young people who have grown up with the war. These diverse training programs open a way for the youth to rediscover a place in society and to contribute to family revenues. By generating jobs, NGOs are providing alternatives to fighting, further weakening the appeal of commandants and warlords who offer little else.

Finally, NGOs have and continue to distribute assistance without concentrating it on areas favoured by any one group in power. In so doing, potentially explosive imbalances such as what currently is occurring in Rwanda have been avoided. 


\section{COORDINATION}

For several years, the NGOs have developed forums for coordination (ACBAR, SWABAC, ICC, ANCB) which allow them to share their experiences and projects by both geographic zone and sector. Presented with a profusion of situations and problems, NGOs seek to reinforce the coordination and planning of program actions. Forums for coordination and planning are now being organized that unite NGOs and UN agencies. This coordination process must be strengthened through the active participation of donors, the UN agencies, and NGOs.

Endowed with tools for monitoring and evaluation (either internal or external), NGOs are improving their technical expertise and the transparency of their actions in the hope that they may thus develop and professionalize their operations for the greater benefit of the Afghan people. The NGO community is well aware of their past failures and current weaknesses. Many of these have been exacerbated by donors stipulations, the donors' failure to monitor projects they financed, and the way by which NGOs have been forced to compete for increasingly limited funds.

\section{THE DONORS}

Virtually all of the agencies working inside Afghanistan depend on assistance from either the national governments of their country of origin or other donors. Without the donors' financial aid, the NGOs would never have been able to complete what they have achieved to date. The Afghans and the government are grateful for the assistance given--without it the problems would be much worse.

To a large extent, the type of assistance activities carried on in Afghanistan are dictated by donor stipulations. Unfortunately, donors have a tendency to force NGOs to classify their programs as either "emergency" or "rehabilitation" without recognizing the diversity of their activities. And as agencies are pushed to justify funding requests on the basis of "emergencies" and "refugee repatriation", it eliminates the majority of the population who cling silently, desperately to the hope for assistance. Those who stayed during the years of struggle are often living in worse conditions than those who became refugees.

The nature of NGO funding by donor countries--on an annual or project-by-project basis--also renders it is extremely difficult for the NGOs to make plans which are long term or geared to the future development of the country. Yet this is precisely what needs to be done if attention is to be turned, as the current situation now requires, from disaster relief to a rational reconstruction of the country. 


\section{RECOMMENDATIONS}

The NGO voice at this meeting, albeit small, is a voice experienced in working among the people of Afghanistan. It is a voice that speaks with knowledge and understanding.

To continue to honour our commitment to the Afghan people, NGOs need the following from donors:

\section{Donors must know the situation}

Anyone familiar with Afghanistan will readily admit that it is a difficult place to work. Security conditions vary across the country, with some always relatively safe, while others have chronic problems. Some areas receive an inordinate amount of current aid, while others in even greater need receive virtually nothing.

Donors are expected to be informed and able to make strategic decisions on how they want their funding utilized. But they must also become informed in order to make that decision.

\section{Donors must identify and reward efficiency}

Donors must target agencies who give good value for money. The bulk of assistance to Afghanistan is implemented by NGOs, and many of these NGOs work extremely effectively. However, in the days of "easy money", a number of NGOs sprang into existence primarily to keep the managers employed. Donors must, therefore, be selective in where they channel their funds and assistance. Of course, this is applicable to whomever they give their support.

\section{Donors must maintain accountability}

Donors must monitor and check on a regular basis, to ensure that funds are well spent, and the needs of the beneficiaries are being addressed. It is a sad fact that during the days of high assistance to Afghanistan, many donors prohibited their staff from going inside the country to monitor activities and outputs. Funds were given with no verifiable system of accountability. Some donors have never seen anything of what they were funding, even after several years. Basic management principles emphasize that tasks must be clearly assigned, and then followed up on. If people are employed to do a job, and their work is not visited by a supervisor for four, five, or six years, it should be no surprise if something goes wrong.

There are currently donors funding work who are very satisfied with the results. However, these donors are actively involved in monitoring and follow-up of work inside Afghanistan.

\section{Donors must commit to areas of need}

The needs of a majority of the people of Afghanistan can only be effectively addressed by a long term strategy. But to do this, donors must think in terms such as "basic needs, development, 
community participation, sustainability." Ironically, while funding is easily available for shortterm emergency situations such as a flash flood, it is far more difficult to secure support for long-term programs addressing one of the root causes of the floods--deforestation.

Support also must be given to initiatives which are considered from the bottom up in order to construct a strategy which will respect the diversity of the present situation in Afghanistan and the complexity of human relations after sixteen years of war.

\section{Donors must make long term plans and commitments}

As the NGOs focus their efforts on rehabilitation and development activities, donors must respond to the needs of changing circumstances. Forests are not regenerated in one year; mine fields are not cleared in three months. Rebuilding trust and responsibility within local communities will be essential if the process of rehabilitation and development is to be effective and lasting. This, however, takes time.

To have the time they need to design and implement strategies for lasting development, NGOs must be given the assurance by donors of long term support. Much valuable time is now wasted as NGOs go through a yearly ritual of searching for funds for programs which are providing critical support to the Afghan people.

\section{Donors must support institutional capacity building}

As part of a long term perspective to the Afghan aid process, donors should support the strengthening of both Afghan government institutions and NGOs. Both are valuable resources to the country in which an investment today will reap long term benefits.

\section{Donors must continue to directly fund NGOs}

There is only one aid process in Afghanistan. Everyone involved--donors, UN agencies, the government and NGOs--are jointly responsible for making it an effective one. All must be prepared to work together in such a way that the strengths of each are acknowledged and maximized. Direct funding to NGOs therefore should be part of a general coordinating framework whose guiding principle is the long term development of Afghanistan. This framework must allow NGOs to adapt their strategies and programs to the realities of the field. It must be recognized that NGOs have and will continue to be the backbone of the aid effort.

\section{Donors must increase their level of support}

Through experience in the field, in-depth knowledge of Afghan culture, and increasingly professional staff, the NGOs' ability to use funds effectively is increasing just as the amount of funds available is decreasing. There is an enormous amount of work that needs to be done in Afghanistan and NGOs have proven that they know what to do and how to do it. They simply need financial support. 


\section{CONCLUSION}

The NGOs are conscious of the responsibility which is theirs due to the fact that they manage $50 \%$ of the emergency aid and over $70 \%$ of the rehabilitation and development assistance currently provided to Afghanistan. They have borne the brunt of the aid work so far, and have learned many valuable lessons in the process. Their programs hold out a promise of peace because they are based on an understanding of the complex social fabric in Afghanistan that has been earned over many years. Through their involvement at the local level, NGOs are and must remain one of the tools of choice for the reconstruction of peace and development in Afghanistan. While the government and UN agencies focus on major infrastructural programs, NGOs can complement their efforts by working in a way unique to the NGOs--at the grass-roots level in close cooperation with local communities.

Investing in people is a long term investment. The people of Afghanistan have survived an inordinate amount of travail, and proven themselves a worthwhile investment. Their tenacity to survive shows their commitment to helping themselves, but they need assistance.

The international community has made numerous public pledges to provide support to people in need at conferences around the world. The Afghan people are in desperate need. Now is the time to give these pledges meaning.

What is your response?

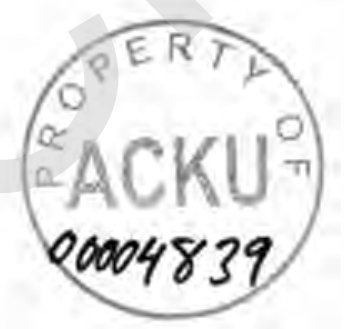



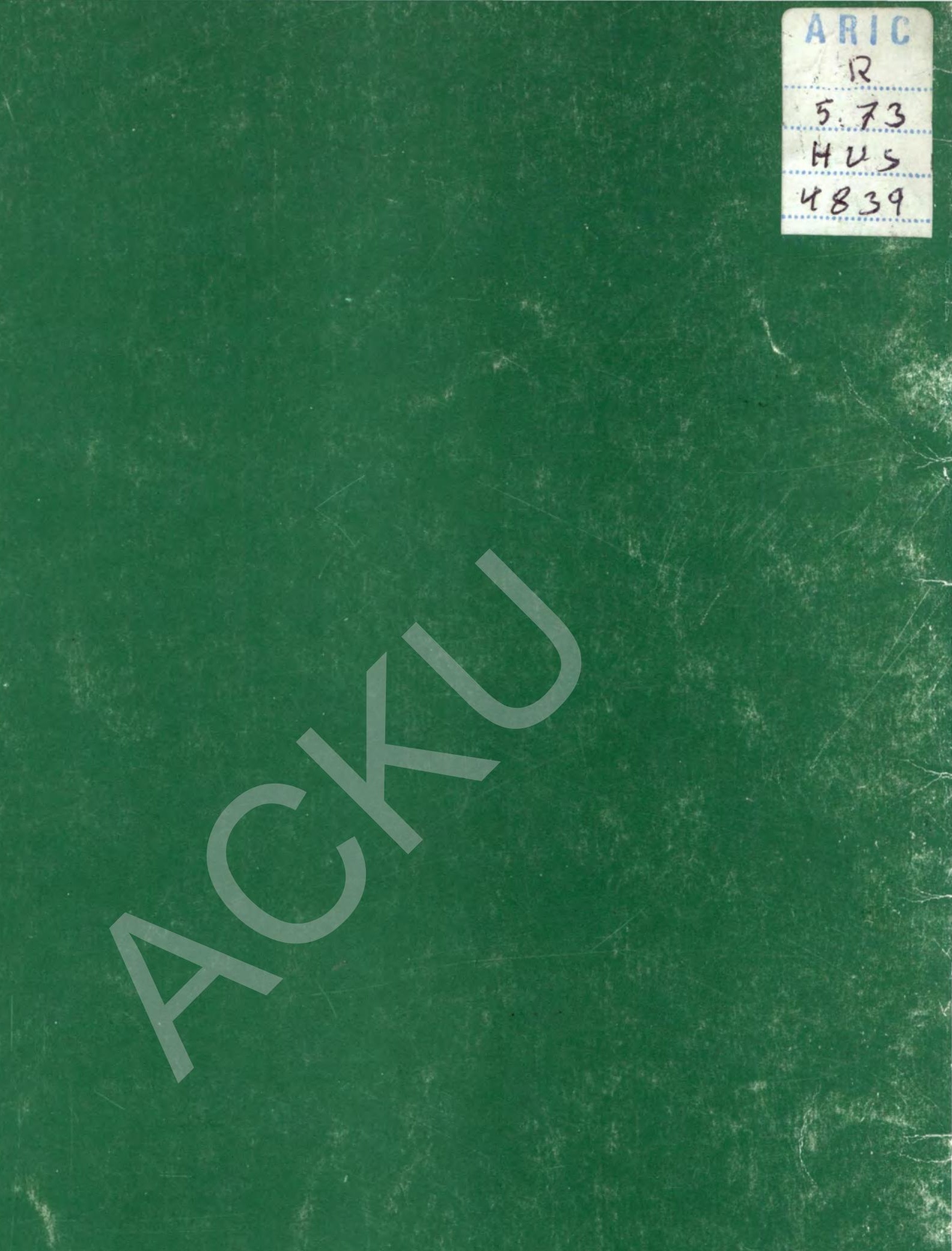

Printed by
PUBLIC ART PRESS

PESHAWAR-PAKISTAN

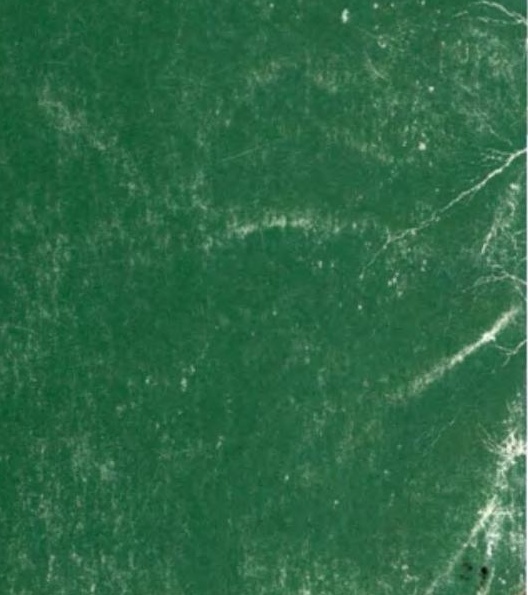

